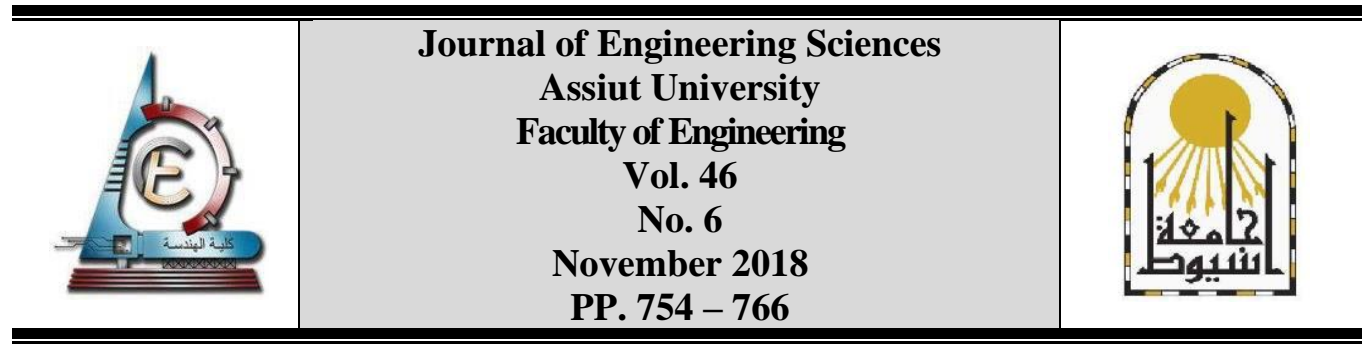

\title{
EVALUATING THE ROLE OF PROJECT MANAGEMENT EDUCATION TOWARDS ENHANCING ARCHITECTURE STUDENTS COMPETENCY SKILLS
}

\author{
Laila M. Khodeir \\ Dept. of Architecture, Faculty of Engineering, Ain Shams University, British University in Egypt, Cairo, Egypt
}

Received 13 August 2018; Accepted 14 September 2018

\begin{abstract}
Teaching project management to Architecture design students is quite challenging. Project management education on university level has to equip students with core competencies, the socalled $21^{\text {st }}$ century ones, which should enable them to cope with market needs. In addition, it has to make full use of the architecture students existing skills. Thus, this paper aims at evaluating the role played by project management education towards the enhancement of the competencies of Architecture students. To achieve the aim of this paper, a survey questionnaire was applied on senior students who have been taught the PM course for 8 successive years at Ain Shams University. Students who attended the course since 2010-2017 participated in the survey, where they had to assess the course after 6 to 1 year(s) of graduation. The number of respondents was almost 300. All participants reported mostly positive impact about the teaching methods in the PM courses. Among the core skills that have been realized through teaching the course were critical thinking, communication, collaboration and creativity.
\end{abstract}

Keywords: Project Management (PM); Education; Competency skills; Architecture Students

\section{Introduction}

Project management has become a growing area, either in practice or in research, according to a survey conducted by [14]. This growing nature is accompanied with the need to provide PM specialists who are equipped with core competencies that enable them to cope with different types of project complexities. In general, the nature of PM is quite unique, where each project is composed of several components, including a wide range of resources and thus requires controlling complexity of components and resources interaction. In addition, PM has to deal with different project attributes, such as urgency, ambiguity and uncertainty, [11].

However, PM education faces a number of challenges. These challenges are either process- related (relevant to teaching methods, techniques and tools), or stakeholdersrelated (relevant to students, instructors, experts and others). Thus this paper focuses on both aspects; firstly, the process challenges through applying different teaching methods and, secondly, the stakeholders' challenges, through evaluating the satisfaction of current students, past students and teaching team with the applied methods. 
The aim of this paper is namely evaluating the role played by PM education towards the enhancement of the competencies of Architecture students. To achieve the aim of this paper, a survey questionnaire was applied on senior students who have been taught the PM course for 8 successive years at Ain Shams University. Students who attended the course since 2010-2017 participated in the survey, where they had to access the course after 6 to 1 years) of graduation. The target sample was architecture students. The number of respondents was almost 300 in all surveys.

\section{Skills and competencies for teaching PM}

Before discussing the essential skills and core competencies for teaching project management, discrimination between both terms "skills" and "competencies" should be done. A competency differs from a skill in that it involves both skills and attitudes as mobilizing resources that enable meeting demands, [9] According to [1], competency is "the ability to apply learning outcomes adequately in a defined context", whereas the skill is "the ability to perform tasks". In conclusion, competency includes skills and attitudes applied in different contextual situations. To achieve the aim of this paper, the coming part will focus on skills that are required to suffice core competencies needed for the PM students to cope with emerging world changes.

\subsection{Essential skills for teaching PM}

The core of learning nowadays is highly relevant to the degree of involving students in problem solving, critical and creative thinking, [12]. From this came the call for skills that are related to teaching project management, the so called " $21^{\text {st }}$ Century skills", which are also named "global competencies", "college and career readiness", "student-centered learning", "next-generation learning", "new basic skills", and "higher-order thinking". These skills typically include both cognitive, non-cognitive skills, in addition to knowledge and attitude, [10]. Teaching these skills raises the need to offer an adaptable educational system that can cope with vast changes, and in the meantime puts an emphasis on these core competencies and intentional ways to prepare students to be able to solve real life problems and PM complicated situations. The call for such educational systems is basically related to the changes in the work force towards technologically-driven environment, globalized knowledge economy and changing expectations of students and changing market needs, [3], [5], [6], and [7]. Nowadays, new jobs have been offered, like sales manager, document manager, customer satisfaction manager, that call for a new type of PM students that are capable and have adequate competencies to do these jobs.

The National Research Council classified the $21^{\text {st }}$ skills that are required to be promoted through teaching in general and through PM in particular into 3 basic groups, interpersonal, intrapersonal and cognitive, as in figure (1). Those skills will lead students to become personally successful, economically productive, and will make them ready for market needs. Although there are different $21^{\text {st }}$ century skills, the focus of this research is mainly on four core skills that should be included in the design of any PM course. These are namely critical thinking, communication, collaboration and creativity. These skills cover the three main categories represented in figure 1. Table 1 offers a summarized description of each skill, showing each skill basic components, what they address and their basic requirements. 


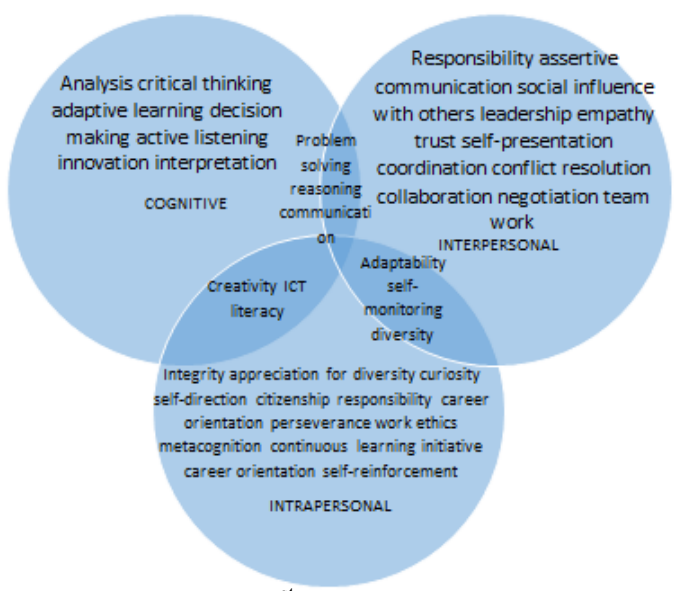

Fig. 1. $21^{\text {st }}$ century skills [2], [8]

Table 1.

Summary of skills description

\begin{tabular}{|l|l|l|}
\hline Author & Skill & Description \\
\hline$[6]$ & Critical thinking & $\begin{array}{l}\text { Includes design, management, solving problems, effective } \\
\text { decision making. } \\
\text { [4] }\end{array}$ \\
& & $\begin{array}{l}\text { Addresses local issues and unclear real world problems. } \\
\text { Requires students to acquire process, interpret and rationalize } \\
\text { conflicting information. }\end{array}$ \\
\hline$[6]$ & Communication & $\begin{array}{l}\text { Includes the ability to communicate effectively, either orally } \\
\text { or written and by listening. } \\
\text { Addresses information and digital literacy, and media. } \\
\text { Requires mastering many forms of rhetoric tasks. }\end{array}$ \\
\hline$[6]$ & Collaboration & $\begin{array}{l}\text { Includes working in a team, contribution, social networking, } \\
\text { and empathy. } \\
\text { Addresses new skills to enable digital collaboration, remote } \\
\text { working and shared working space. } \\
\text { Requires students to develop collective intelligence. }\end{array}$ \\
\hline$[6]$ & Creativity & $\begin{array}{l}\text { Includes the generation of new ideas, concepts or products. } \\
\text { While Innovation includes the realization of such ideas. } \\
\text { Addresses economic and social entrepreneurialism, leadership. } \\
\text { Requires giving students experiences with situations in which } \\
\text { there is no definite answer. }\end{array}$ \\
\hline
\end{tabular}

\subsection{Assessment practices for PM skills}

Without being able to measure the impact of the application of teaching methods, the expected benefits will not work. Here comes the role of assessment practices for what has been taught. However, the type of assessment required will need to have an adapted nature in order to cope with the wide range of skills to be transferred. In general, the OPS (2016) offered a number of basic topics to be assessed, where this paper builds upon these topics in the assessment practices implemented in the case study courses. These topics include:

- The role of curriculum policy in focusing on the four core skills previously discussed.

- The role of students in leaning and developing the 4 core skills.

- The needed changes to the structure of curriculum documents. 
- Alternatives for providing students with access to experiential learning opportunities.

- The reflection of the developed skills on the students' graduation projects.

\section{Analysis of case study course}

In this part of the paper, the case study of Feasibility studies and Project management course, offered to senior mainstream Architecture students at Ain Shams University shall be evaluated. The course has been taught by the author for 8 successive years, which enabled the experimenting and improvement of the course. The focus of the analysis is on the skills each method of teaching targeted. Findings of the course assessment of students' and teaching assistant's assessment are explained further. It worth mentioning that the teaching methods applied in the first course have changed along the 8 years of its lifetime. In general, the courses aimed at enhancing collaboration and teamwork activities in addition to other core skills. Thus the activities that were performed throughout the courses were either in-class/tutorial or outdoor.

Figure 2 shows the classification of the teaching and learning methods that were adopted through the PM course, where they included in-class and outdoor activities, some activities were led by course instructors, while others were led by the students themselves. Among the activities which targeted team building was assessing the awareness of students towards acting as a team, which is equivalent to the performing stage in team building stages. Students were asked to divide a mandala drawing evenly among all members then each one individually enlarged their part in double scale. Afterwards, each one had to finish their part, and finally after they were done, they had to bind all the drawings together on one sheet and submit them, Figure 3. This activity evoked the deficiencies in each group, where not all groups coordinated with each other along the process, while some groups acted as real team.

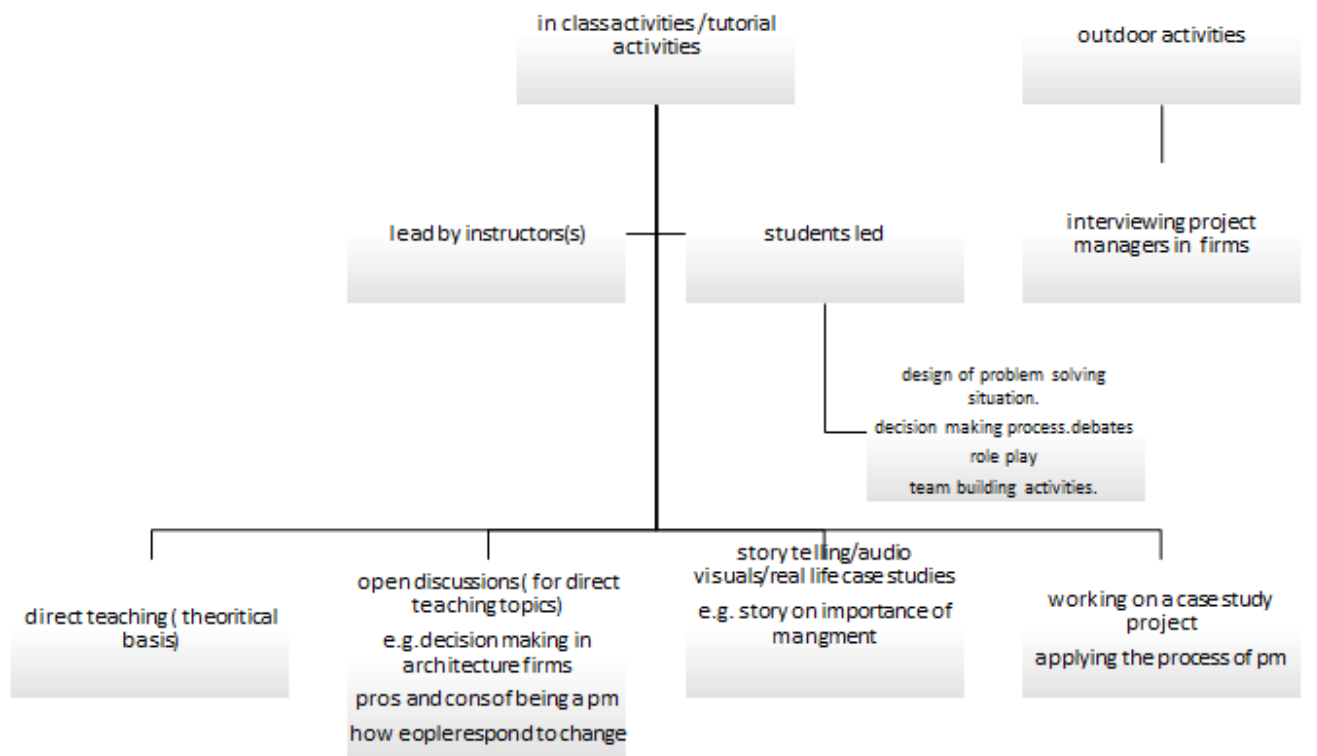

Fig. 2. Classification of methods and activities included in PM course

The final set of in-class activities included working on the processes of project initiation and planning for a real project that was adopted by the teaching team, the project was entitled "Egyptian community bank". Figure 4 shows project summery and location. Through this 
project student had to merge the knowledge they already have as architecture students, e.g., types of contracts, Estimating Quantities, etc., together with the new knowledge they acquired through the PM course. Students worked each session on producing project scope statement, identifying stakeholders' requirement, through role play, and planning time schedule and preliminary budget for the project. Students were able to use some software programs that are popular and available to produce their final schedules.
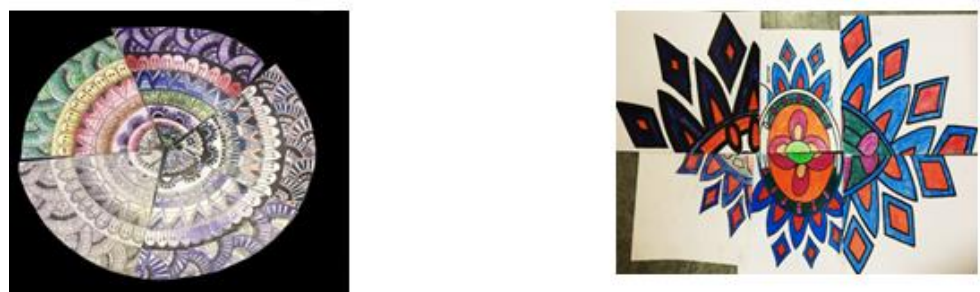

Fig. 3. Team building activitv

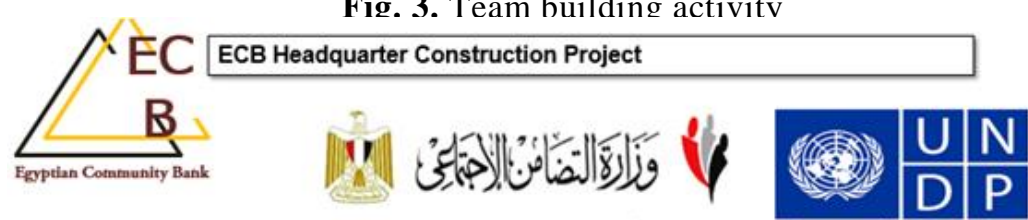

Egyptian Community Bank

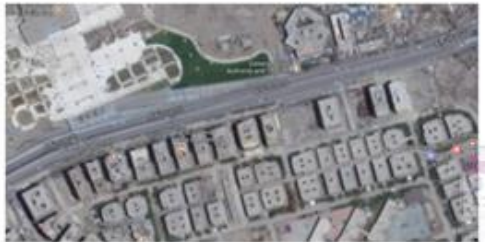

Serves the poor / low-income groups

Increases financial security/access to credit

Invests in poor-oriented projects

Community service \& capacity building

Fig. 4. Summary of the project the students had to work on

The applied methods of assessment in the course included assessing the four main core skills that have been integrated through teaching and learning methods. The assessment took the form of both in-class feedback and outdoor one, in order to comprehensively assess students. The outdoor methods included allowing students to experience learning opportunities. The reflection of the developed skills on graduation projects was assessed further through the questionnaire of students.

\section{Evaluation of the role of PM education on architecture students}

It is important to assess the effectiveness of any learning process to make sure that the end user or the student has perceived what they really need, and what they actually expected. The normal grading system of final exams might sometimes be distracting, or at least might not reflect the actual satisfaction of the students. Thus this part of the paper will evaluate the outputs of teaching courses. The results were assessed through surveying more than 300 students who attended the PM course since 2010 and till 2017. The response rate of students from the last two years was generally high, almost $65 \%$ of the students, which is logical as the survey was created only two years ago. This also had a positive effect on the survey results, where it allowed the past students to share their opinion as experts as they had more than 5 years of experience at the time they participated in the survey. 


\subsection{General background of respondents}

The figures 5 and 6 show the general background of respondents and the year they had the course in. Figure 6 shows the current affiliation of respondents, where 54\% are fresh graduates and the rest were architects, project managers, teaching assistants, technical office managers, contract engineers, or site managers. Figure 7 shows the level of prior knowledge on the field of PM, where most of the respondents (75\%) did not have any prior knowledge on the field.

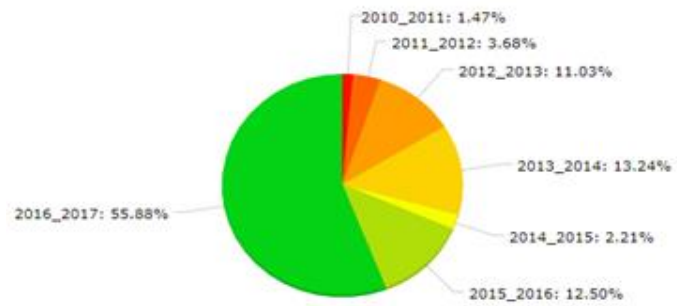

Fig. 5. Percentage of respondents who attended the PM course throughout the years

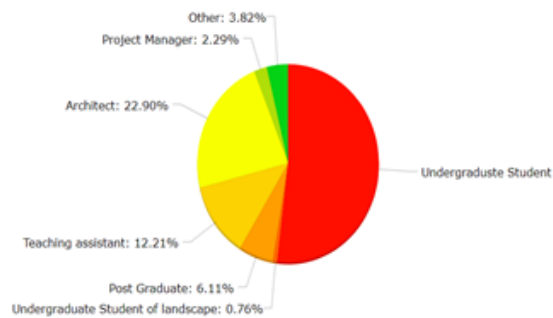

Fig. 6. Current affiliation of PM course respondents

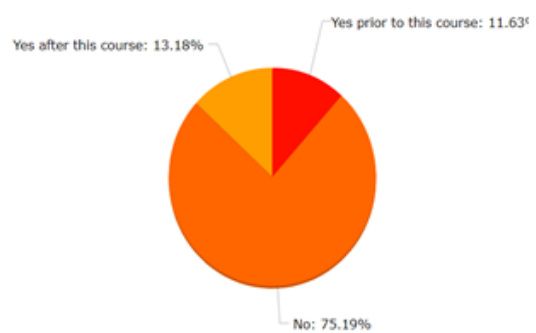

Fig. 7. The level of prior knowledge on the field of PM

\subsection{Assessment of course satisfaction}

Most respondents were highly satisfied with the course objectives, its outline, assessment, grading system and feedback methods, figure 8. However, some of the respondents were not highly satisfied with the reference books offered, since only a list of references was offered. Students were also not agreeing on the course duration, with a standard deviation of 1.04, figure 11. Students of PM course suggested to increase the duration of the course, and to start taking preliminary management courses earlier than year 4. It is clear from the statistical analysis of mean value that students were highly satisfied with how the course was coping with the nature of architecture students; however, they were less satisfied with coping with enhancements in the field of PM. Satisfaction of respondents to teaching methods either in lectures or in tutorials was quite high as detected in figure 9 , whereas less satisfaction was detected for the students-led methods including selfpresentation and self-evaluation of each other. This is most probably linked to the fear of bias towards each other. Some students mentioned that they preferred to be assessed by the instructor. Respondents were less satisfied with guest lectures. This can be explained in terms of the fact that guest lectures were newly added to the course (only in the past 4 years). Figure 10 shows a detailed evaluation of each teaching method adopted in both courses. 


\begin{tabular}{|c|c|c|c|c|c|c|c|c|c|c|c|c|}
\hline & \multicolumn{2}{|c|}{$\begin{array}{l}\text { Completely Dissatizfied } \\
\text { (1) }\end{array}$} & \multicolumn{2}{|c|}{$\begin{array}{l}\text { Dissutisfied } \\
\text { (2) }\end{array}$} & \multicolumn{2}{|c|}{$\begin{array}{c}\text { Neutral } \\
\text { (3) }\end{array}$} & \multicolumn{2}{|c|}{$\begin{array}{l}\text { Sotisfied } \\
\text { (4) }\end{array}$} & \multicolumn{2}{|c|}{$\begin{array}{l}\text { Toually suthfied } \\
\text { (5) }\end{array}$} & \multirow[b]{2}{*}{0} & \multirow[b]{2}{*}{ \pm} \\
\hline & I & x & $\Sigma$ & $\mathbf{x}$ & $\Sigma$ & $x$ & $\Sigma$ & $\times$ & $\Sigma$ & $x$ & & \\
\hline Course objectives & - & . & - & - & $5 x$ & 4.24 & $75 x$ & 63.56 & $38 x$ & 32.20 & 4.28 & 0.54 \\
\hline Course outline & . & . & $3 x$ & 2.52 & $11 x$ & 9.24 & $69 x$ & 57.98 & $36 x$ & 30.25 & 4.16 & 0.69 \\
\hline Course in-class assessment & $1 x$ & 0.85 & $2 x$ & 1.71 & $14 x$ & 11.97 & $50 x$ & 42.74 & $50 x$ & 42.74 & 4.25 & 0.80 \\
\hline Individual quizzes & - & - & $10 x$ & 8.55 & $24 x$ & 20.51 & $56 x$ & 47.86 & $27 x$ & 23.08 & 3.85 & 0.87 \\
\hline Group presentations & $2 \mathrm{x}$ & 1.68 & $2 x$ & 1.68 & $21 x$ & 17.65 & $56 x$ & 47.06 & $38 x$ & 31.93 & 4.06 & 0.85 \\
\hline Course reference books and notes & $1 x$ & 0.84 & $14 x$ & 11.76 & $37 x$ & 31.09 & 49x & 41.18 & $18 x$ & 15.13 & 3.58 & 0.92 \\
\hline Course duration & $2 x$ & 1.71 & $33 x$ & 28.21 & $26 x$ & 22.22 & $44 x$ & 37.61 & $12 x$ & 10.26 & 3.26 & 1.04 \\
\hline Tutorial duration & $4 x$ & 3.45 & $9 x$ & 7.76 & $28 x$ & 24,14 & $56 x$ & 48.28 & $19 x$ & 16.38 & 3.66 & 0.96 \\
\hline Grading system & . & . & $2 x$ & 1.69 & $10 x$ & 8.47 & $57 x$ & 48.31 & $49 x$ & 41.53 & 4.30 & 0.70 \\
\hline Feedbuxk system & . & . & $1 x$ & 0.85 & $13 x$ & 11.02 & $40 x$ & 33.90 & $64 x$ & 54.24 & 4.42 & 0.72 \\
\hline Coping with advances in PM field & . & . & $2 x$ & 1.74 & $30 x$ & 26.09 & $61 x$ & 53.04 & $22 x$ & 19.13 & 3.90 & 0.72 \\
\hline ping w & . & . & $x$ & 1.71 & $1 x$ & 17.95 & $65 x$ & 55.56 & $29 x$ & 24.79 & .03 & ( \\
\hline
\end{tabular}

Fig. 8. Assessment of students and graduates satisfaction with generic course aspects and attributes

\begin{tabular}{|c|c|c|c|c|c|c|c|c|c|c|c|c|}
\hline & \multicolumn{4}{|c|}{ Completely Dissatisfied Dissatisfied } & \multirow{2}{*}{\multicolumn{2}{|c|}{$\begin{array}{l}\text { Meutral } \\
\text { (3) }\end{array}$}} & \multirow{2}{*}{\multicolumn{2}{|c|}{$\begin{array}{l}\text { Satisfied } \\
\text { (4) }\end{array}$}} & \multirow{2}{*}{\multicolumn{2}{|c|}{$\begin{array}{l}\text { Completely Satisfiod } \\
\text { (5) }\end{array}$}} & \multirow{3}{*}{ 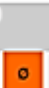 } & \multirow[b]{3}{*}{ \pm} \\
\hline & & & & & & & & & & & & \\
\hline & $\Sigma$ & x & $\Sigma$ & * & $\varepsilon$ & $x$ & $\Sigma$ & $*$ & $\Sigma$ & * & & \\
\hline Methods of teaching used in lect.- & . & . & . & . & $10 x$ & 8.70 & $56 x$ & 48.70 & $49 x$ & 42.61 & 4.34 & 0.63 \\
\hline Methods of practice used in tutor... & $1 \mathrm{x}$ & 0.88 & $4 x$ & 3.51 & $15 x$ & 13.16 & $46 x$ & 40.35 & $48 x$ & 42.11 & 4.19 & 0.86 \\
\hline Students' presentations & $4 x$ & 3.48 & $2 x$ & 1.74 & $27 x$ & 23.48 & $57 x$ & 49.57 & $25 x$ & 21.74 & 3.84 & 0.90 \\
\hline Self evaluation of presentations & $5 x$ & 4.42 & $4 x$ & 3.54 & $30 x$ & 26.55 & $54 x$ & 47.79 & $20 x$ & 17.70 & 3.71 & 0.95 \\
\hline Guest lectures presentations & $4 x$ & 3.60 & $11 x$ & 9.91 & $32 x$ & 28.83 & $43 x$ & 38.74 & $21 x$ & 18.92 & 3.59 & 1.02 \\
\hline
\end{tabular}

$\square$ Anthmetic average (0)

$\square$ Standard deviation ( $(*)$

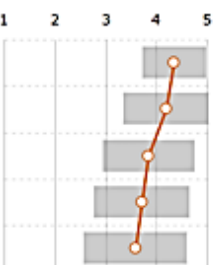

Fig. 9. Assessment of sudents and graduates satisfaction with generic methods of teaching used and asessment techmiques

\begin{tabular}{|c|c|c|c|c|c|c|c|c|c|c|c|c|}
\hline & \multicolumn{2}{|c|}{$\begin{array}{l}\text { Weak } \\
\text { (1) }\end{array}$} & \multicolumn{2}{|c|}{$\begin{array}{l}\text { Fair } \\
\text { (2) }\end{array}$} & \multicolumn{2}{|c|}{$\begin{array}{l}\text { Good } \\
\text { (3) }\end{array}$} & \multicolumn{2}{|c|}{$\begin{array}{l}\text { Very sood } \\
\text { (4) }\end{array}$} & \multicolumn{2}{|c|}{$\begin{array}{l}\text { Excellent } \\
\text { (5) }\end{array}$} & \multirow[b]{2}{*}{ o } & \multirow[b]{2}{*}{ \pm} \\
\hline & $\Sigma$ & $\mathbf{x}$ & $\Sigma$ & $\mathbf{x}$ & $\Sigma$ & $\mathbf{x}$ & $\Sigma$ & $x$ & $\varepsilon$ & $x$ & & \\
\hline The project manager selection & $2 x$ & 1.89 & $7 x$ & 6.60 & $45 x$ & 42.45 & $40 x$ & 37.74 & $12 x$ & 11.32 & 3.50 & 0.85 \\
\hline Team building activities & $2 x$ & 1.83 & $8 x$ & 7.34 & $25 x$ & 22.94 & $54 x$ & 49.54 & $20 x$ & 18.35 & 3.75 & 0.50 \\
\hline Designing a decision making situation & $1 \mathrm{x}$ & 0.93 & $5 x$ & 4.67 & $31 x$ & 28.97 & $50 x$ & 46.73 & $20 x$ & 18.69 & 3.78 & 0.84 \\
\hline Creating scope statement: & $3 x$ & 2.78 & $9 \mathrm{x}$ & 8.33 & $36 x$ & 33.33 & $45 x$ & 41.67 & $15 x$ & 13.89 & 3.56 & 0.93 \\
\hline Cresting wes & $4 x$ & 3.70 & $7 \mathrm{x}$ & 6.48 & $32 x$ & 29.63 & $41 x$ & 37.96 & $24 x$ & 22.22 & 3.69 & 1.01 \\
\hline Cost and time estimation & $3 x$ & 2.73 & $11 x$ & 10.00 & $30 x$ & 27.27 & $45 x$ & 40.91 & $21 x$ & 19.09 & 3.64 & 0.99 \\
\hline Using scheduling software & $9 \mathrm{x}$ & 8.49 & $18 x$ & 16.98 & $33 x$ & 31.13 & $30 x$ & 28.30 & $16 x$ & 15.09 & 3.25 & 1.16 \\
\hline Risk management & $5 x$ & 4.76 & $21 x$ & 20.00 & $31 x$ & 29.52 & $30 x$ & 28.57 & $18 x$ & 17.14 & 3.33 & 1.12 \\
\hline Contract administration & $5 \mathrm{x}$ & 4.72 & $17 x$ & 16.04 & $30 x$ & 28.30 & $32 x$ & 30.19 & $22 x$ & 20.75 & 3.46 & 1.13 \\
\hline Drawing S- curve & $3 x$ & 2.83 & $11 x$ & 10.38 & $333 x$ & 31.13 & $39 x$ & 36.79 & $20 x$ & 18.87 & 3.58 & 1.00 \\
\hline Using economic evaluation tools & $3 x$ & 2.83 & $17 x$ & 16.04 & $40 x$ & 37.74 & $31 x$ & 29.25 & $15 x$ & 14.15 & 3.36 & 1.01 \\
\hline Stakeholders analysis & $2 x$ & 1.82 & $7 x$ & 6.36 & $24 x$ & 21.82 & $46 x$ & 41.82 & $31 x$ & 28.18 & 3.88 & 0.96 \\
\hline
\end{tabular}
Standard deviation (*)

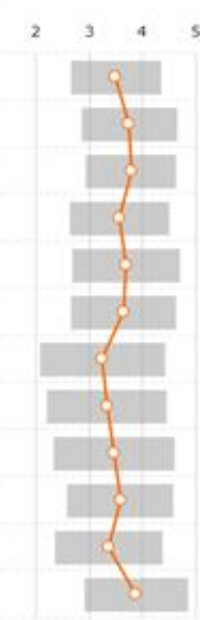

Fig. 10. Students and graduates satisfaction with in-class tutorial activities in PM 


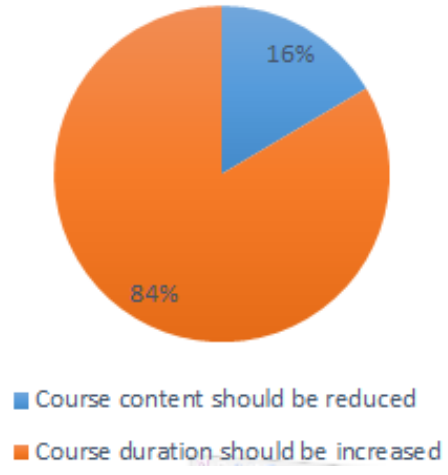

Fig. 11. Degree of respondants agreement on course timing and duration

\subsection{Assessment of core skills efficiency}

In this part of the assessment, the emphasis is on the satisfaction of respondents with the core skills they acquired through the courses. Figure 12 makes it clear that both courses played a role in equipping students with core skills. However, in the principles of management course, leadership skills were more emphasized, which could be explained in light of the nature of the course and its limited theoretical content in comparison to the PM course. Team work was clearly the highest agreed-upon skill to be delivered by both courses. Figure 13 and 14 show how respondents benefited most from both courses and how they remarked that the courses had an influence on them. Most respondents mentioned they benefitted most from the information, new terminology and the interviews they did themselves with architecture-related companies. Some other responses included: "mix between learning and creativity, my thinking towards real situations, and how management process work". Almost $70-75 \%$ in both courses agreed that having such courses very much

\begin{tabular}{|c|c|c|c|c|c|c|c|c|c|c|c|c|}
\hline & \multicolumn{2}{|c|}{$\begin{array}{l}\text { Not at all } \\
\text { (1) }\end{array}$} & \multicolumn{2}{|c|}{$\begin{array}{l}\text { Little } \\
\text { (2) }\end{array}$} & \multicolumn{2}{|c|}{$\begin{array}{c}\text { Neutral } \\
\text { (3) }\end{array}$} & \multicolumn{2}{|c|}{$\begin{array}{l}\text { Much } \\
\text { (4) }\end{array}$} & \multicolumn{2}{|c|}{$\begin{array}{l}\text { Very much } \\
\text { (5) }\end{array}$} & \multirow[b]{2}{*}{$\bullet$} & \multirow[b]{2}{*}{ \pm} \\
\hline & $\boldsymbol{\Sigma}$ & * & $\Sigma$ & $\boldsymbol{*}$ & $\Sigma$ & ж & $\Sigma$ & $\mathbf{x}$ & z & x & & \\
\hline Leadership & $7 x$ & 6.14 & $14 x$ & 12.28 & $38 x$ & 33.33 & $45 x$ & 39.47 & $10 x$ & 8.77 & 3.32 & 1.01 \\
\hline Conftict resolution & $3 \mathrm{x}$ & 2.75 & $9 x$ & 8.26 & $37 x$ & 33.94 & $52 x$ & 47.71 & $8 x$ & 7.34 & 3.49 & 0.86 \\
\hline Team work & $3 x$ & 2.63 & $5 \mathrm{x}$ & 4.39 & $26 x$ & 22.81 & $58 x$ & 50.88 & $22 x$ & 19.30 & 3.80 & 0.89 \\
\hline Persuasion and negotiation & $3 x$ & 2.65 & $11 \mathrm{x}$ & 9.73 & $24 \mathrm{x}$ & 21.24 & $54 x$ & 47.79 & $21 x$ & 18.58 & 3.70 & 0.97 \\
\hline Presentation skills & $6 x$ & 5.31 & $8 x$ & 7.08 & $35 \mathrm{x}$ & 30.97 & $37 x$ & 32.74 & $27 x$ & 23.89 & 3.63 & 1.09 \\
\hline Communication skilts & $3 \mathrm{x}$ & 2.68 & $9 x$ & 8.04 & $26 \mathrm{x}$ & 23.21 & $55 x$ & 49.11 & $19 \mathrm{x}$ & 16.96 & 3.70 & 0.94 \\
\hline Motivation skills & $3 x$ & 2.65 & $11 \mathrm{x}$ & 9.73 & $23 x$ & 20.35 & $44 x$ & 38.94 & $32 x$ & 28.32 & 3.81 & 1.04 \\
\hline Scheduleing skills & $2 x$ & 1.79 & $6 x$ & 5.36 & $32 x$ & 28.57 & $46 x$ & 41.07 & $26 x$ & 23.21 & 3.79 & 0.92 \\
\hline Time Management skills & $1 \mathrm{x}$ & 0.88 & $11 \mathrm{x}$ & 9.73 & $33 \mathrm{x}$ & 29.20 & $386 x$ & -33.63 & $30 x$ & 26.55 & 3,75 & 0.99 \\
\hline
\end{tabular}

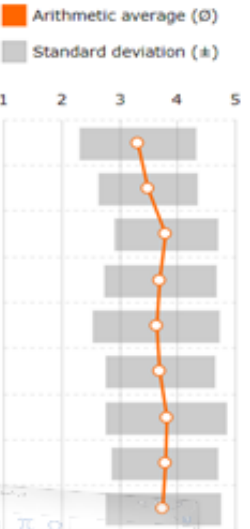

Fig.12. Assessment of efficiency of core skills transformed in PM 


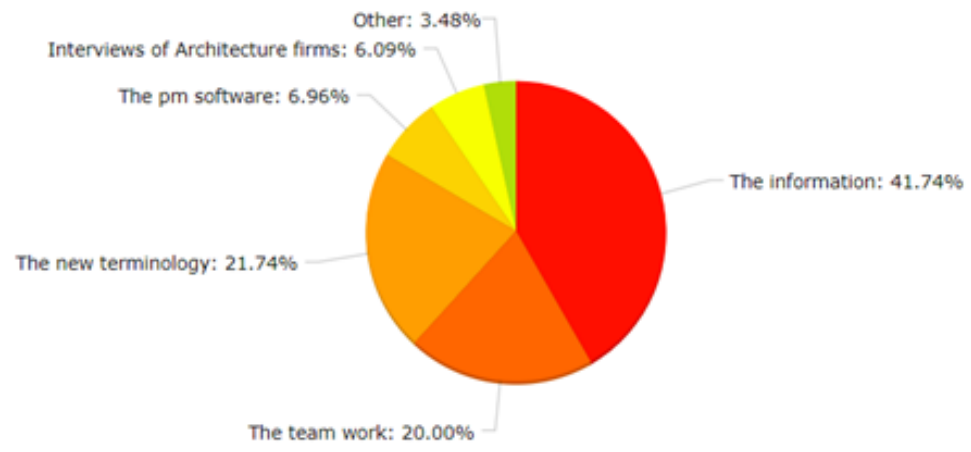

Fig. 13. Benefits of the course on the respondents

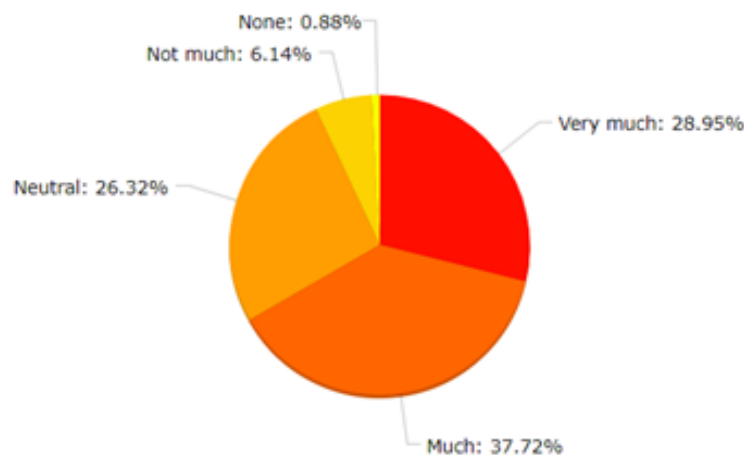

Fig. 14. Percentage of respondents who believe the course influenced them to continue working in PM career

\subsection{Reflection of the course on other courses and on graduation project}

The impact of the management courses acquired on other related courses and on the graduation project of students was assessed from the respondent's perception, where almost $70 \%$ of them found the courses taken beneficial or highly beneficial before any other management courses, figure 15 . Also most respondents found that the courses helped them as graduates $(55 \%)$. Others believed they helped in graduation projects $(30 \%)$ and the rest found them useful for entering architecture competitions and doing academic research, figure 16.

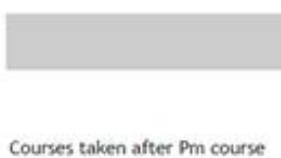

Fig. 15. Asses

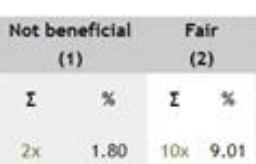

It doesn't help: $2.15 \%$

As an academic it helps me in my research: $5.38 \%$
Arithmetic average (ø)

Standard deviation $( \pm$ )

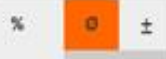

\begin{tabular}{l|ll}
27.03 & 3.82 & 0.99
\end{tabular}

erwards

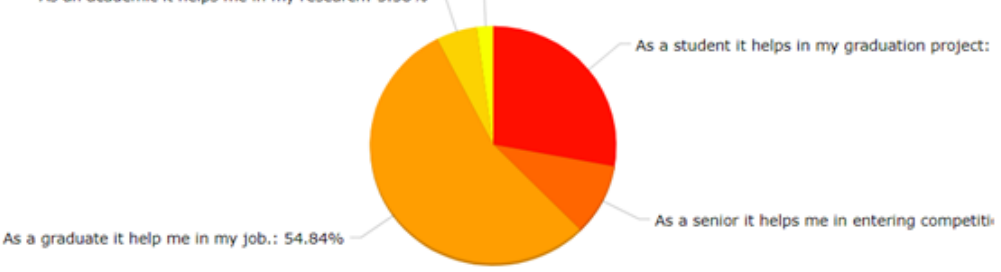

Fig.16. Responses of the reflection of the PM course on employment and graduation project 


\subsection{Impact of teaching methods on teaching team}

The teaching assistance team of the PM course along the years included almost 12 teaching members. The author sent the evaluation survey to only 10 of them and received the reply of 7. The following figures show the results of the Teaching Assistants' evaluation, their degree of engagement and how it affected their own skills. The degree of engagement of the teaching team is shown in figure 17, where the team was highly involved in the in-class group activities which contributed to most of the course time, whereas the team had less involvement in designing unseen exam questions and showed a medium involvement in the process of setting content and selection of teaching methods. Figure 18 shows how the teaching team appreciated their roles in the courses, where they highly agreed that their roles matched their skills, and even gave them the opportunity to learn more skills. Most of the team agreed that participating in them had very much improved their teaching experience $(85 \%)$, while $70 \%$ found it to add to their core competency skills. Upon asking the team to describe their experience in teaching those courses, they used words like "trustworthy, cooperative, and organized".
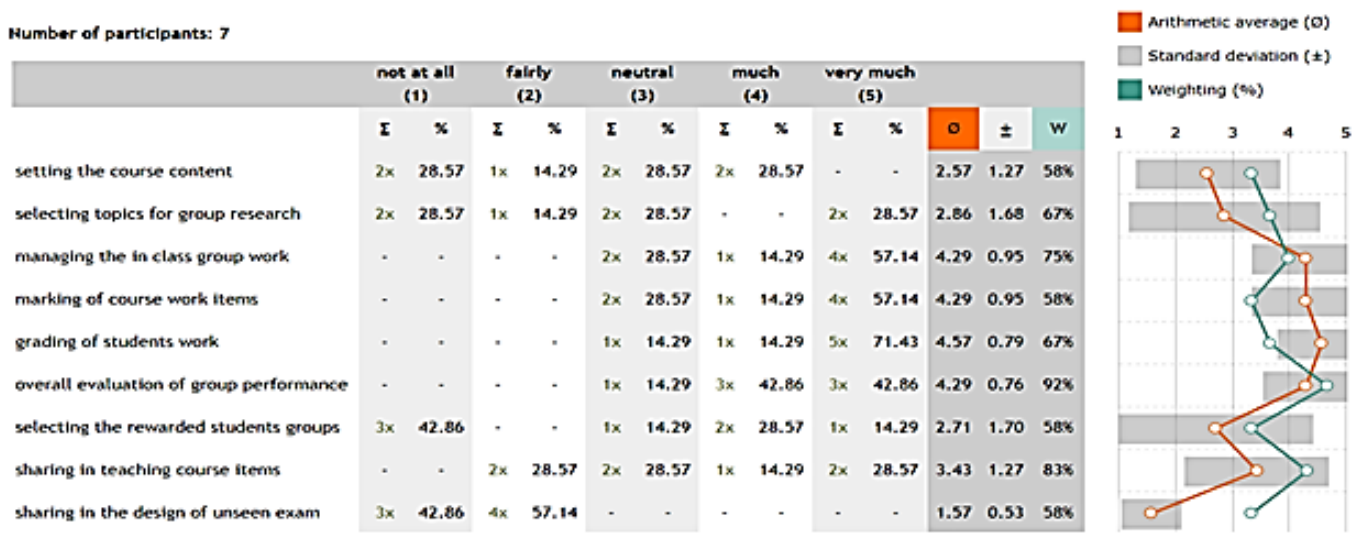

Fig. 17. Degree of engagement in the course policy, structure and activities
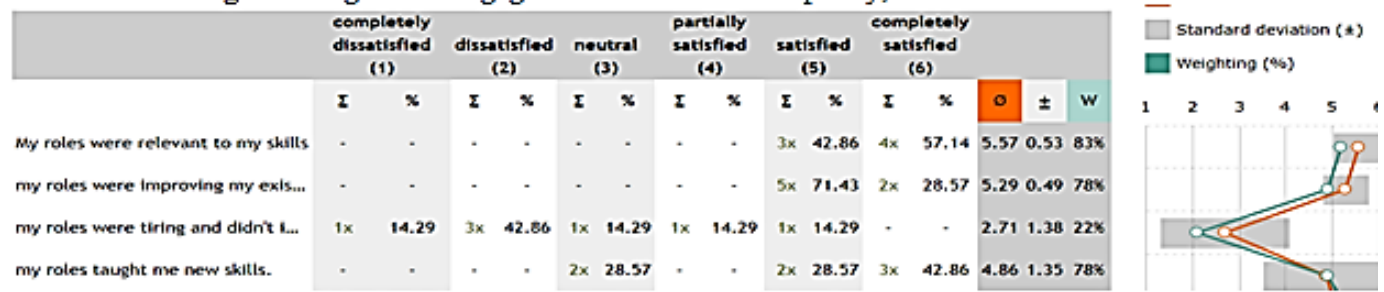

Fig. 18. Satisfaction with the roles assigned to each team member

\section{Conclusions}

To achieve the paper objective, based on the analysis of the case study course, the learning methods that were used throughout the course were classified in terms of the core skill they supported, in addition to the assessment practice for assessing the efficiency of each skill. The assessments were either done by the instructor through direct methods, including exams, inclass quizzes and observation of students' responses, or were done by students themselves, and guided by criteria and feedback assessment forms designed by the instructor to ensure consistency, table 2 . This table shows how teaching methodologies that were adopted in the case study course covered all four core skills that are essential for preparing architecture PM students for their future career. In addition, these methods were adapted to the nature of architecture 
design students, and made good use of the skills they have acquired, including visual design, manual drawing, coloring techniques, and using computerized visualization.

Table 2.

The skills transferred through each learning method in PM course, Author.

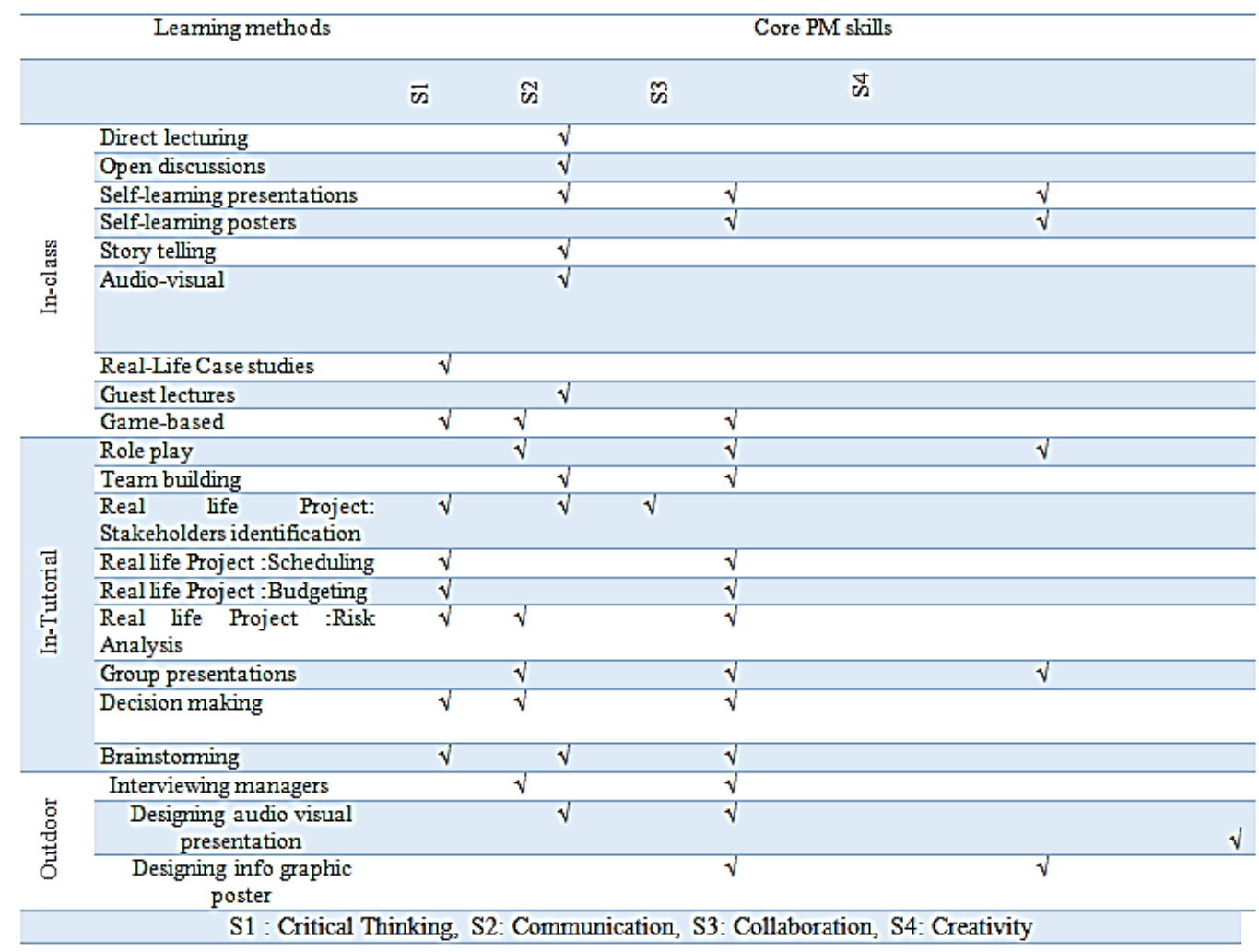

Upon the findings of the assessment of respondents, whether current students, graduates or teaching team, to teaching methods that were applied in the PM courses, it was evident that participants reported mostly positive impact from the teaching methods of the PM courses. Thus this paper showed that teaching PM could be eligible enough to face challenges students face through real world. It could enhance their core competency skills including the $4 \mathrm{Ss}$; Critical thinking, collaboration, communication and creativity.

\section{REFERENCES}

[1] Cedefop (2014). Terminology of European Education and Training Policy (Second Edition) - A selection of 130 key terms. Luxembourg: Publications Office. Retrieved from: www.cedefop.europa.eu/EN/Files/4117_en.pdf.

[2] C21 Canada (Canadians for 21st Century Learning and Innovation). (2012). Shifting Minds: A $21^{\text {st }}$ Century Vision of Public Education for Canada. Retrieved from: www.c21canada.org/wp-content/uploads/2012/11/Shifting-Minds- Revised.pdf.

[3] Dede, C. (2010). Comparing Frameworks for $21^{\text {st }}$ Century Skills.

[4]Drake, S.M. (2014). Designing across the Curriculum for "Sustainable Well-being": A $21^{\text {st }}$ Century Approach. 
[5] Dumont, H., Istance, D., \& Benavides, F. (Eds.), (2010). The Nature of Learning: Using Research to Inspire Practice. Paris: Educational Research and Innovation, OECD Publishing. Retrieved from: http://dx.doi. org/10.1787/9789264086487-en.

[6] Fullan, M., \& Langworthy, M. (2014). A Rich Seam: How New Pedagogies Find Deep Learning. London: Pearson.

[7] Griffin, P.E., McGaw, B., \& Care, E. (Eds.). (2012). Assessment and Teaching of $21^{\text {st }}$ Century Skills (ATC21S). Dordrecht: Springer. Retrieved from: www.atc21s.org.

[8] National Research Council. (2012, July). Education for Life and Work: Developing Transferable Knowledge and Skills in the $21^{\text {st }}$ Century. Report Brief. Washington, DC: National Academies Press. Retrieved from: http:// sites.nationalacademies.org/cs/groups/dbassesite/documents/webpage/ dbasse_070895.pdf.

[9] OECD (Organisation for Economic Co-operation and Development). (2003). Key competencies for a successful life and well-functioning society. The definition and selection of key competencies: Executive summary. Summary of report by S.D. Rychen \& L.H. Salganik (Eds.). Göttingen: Hogrefe and Huber Publishers. Retrieved from: www.oecd.org/dataoecd/47/61/35070367. pdf.

[10] Ontario Public Service Endeavors (OPS), (2016). 21 ${ }^{\text {st }}$ Century Competencies Towards Defining $21^{\text {st }}$ Century Competencies for Ontario.

[11] Pich, M.T., Loch, C.H., De Meyer, A. (2002), On Uncertainty, Ambiguity, and Complexity in Project Management. Manage. Sci., 48, 1008-1023.

[12] Trilling, B., \& Fadel, C. (2009). $21^{\text {st }}$ Century Skills: Learning for life in our times. San Francisco: Jossey-Bass.

[13] Upitis, R. (2014, November 8). Creativity: The State of the Domain. In People for Education, Measuring What Matters. Toronto. Retrieved from: http:// peopleforeducation.ca/measuring-what-matters/domain/creativity-and-innovation/.

[14] Whittington, R., Pettigrew, A., Simon, P., Fenton, E., Conyon, M. (1999), Change and Complementarities inzthe New Competitive Landscape: A European Panel Study, 19921996. Organ. Sci., 10, 583-600. 
تقييم أثر تدريس مواد اداره المشروعات على تحفيز مهارات وكفاءات طلبه الهندسة المعمارية

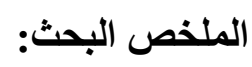

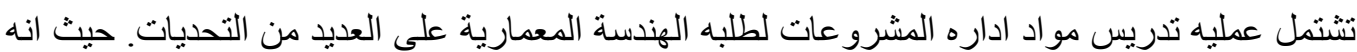

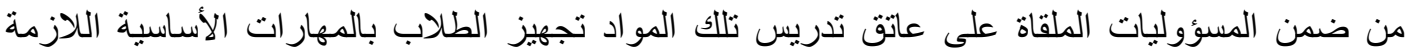

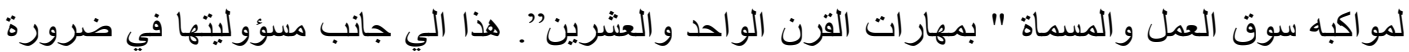

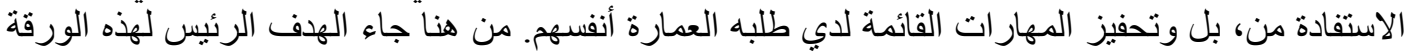

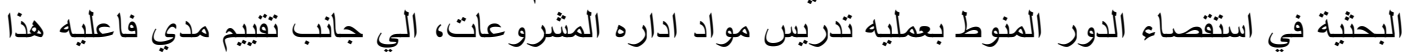

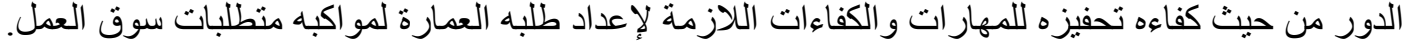

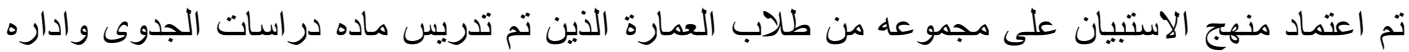

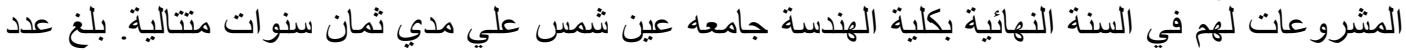

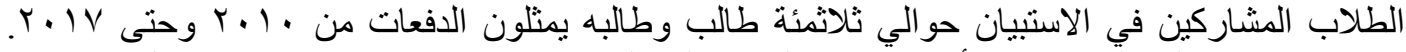

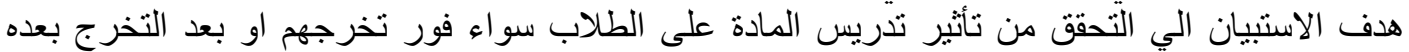

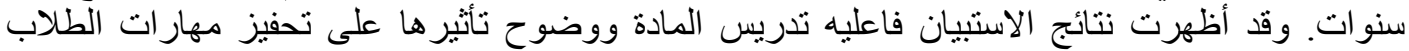

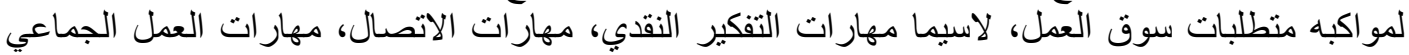
و المهار ات الإبداعية. 